\title{
Two thresholds determine climatic control of forest-fire size in Europe
}

L. Loepfe ${ }^{1}$, A. Rodrigo ${ }^{1,2}$, and F. Lloret ${ }^{1,2}$

${ }^{1}$ Center for Ecological Research and Forestry Applications (CREAF), Bellaterra, Spain

${ }^{2}$ Autonomous University of Barcelona, Bellaterra, Spain

Received: 3 May 2012 - Accepted: 29 June 2012 - Published: 23 July 2012

Correspondence to: L. Loepfe (lasse.loepfe @gmail.com)

Published by Copernicus Publications on behalf of the European Geosciences Union.

\section{Two thresholds determine climatic control of forest-fire size in Europe \\ L. Loepfe et al.}

\section{Title Page}

Abstract Introduction

Conclusions References

Tables Figures

14

4

Back

Close

Full Screen / Esc

Printer-friendly Version

Interactive Discussion 


\section{Abstract}

Fire weather indices predict fire extent from meteorological conditions assuming a monotonic function; this approach is frequently used to predict future fire patterns under climate change scenarios using linear extrapolation. However, the relationship

5 between weather and fire extent may potentially depend on the existence of fuel humidity thresholds above which this relationship changes dramatically, challenging this statistical approach. Here we combine the continuous and the threshold approaches to analyze satellite-detected fires in Europe during 2001-2010 in relation to meteorological conditions, showing that fire size response to increasing dryness follows a ramp function, i.e. with two plateaus separated by a phase of monotonic increase. This study confirms that at a continental and a high-resolution temporal scales, large fires are very unlikely to occur under moist conditions, but it also reveals that fire size stops to be controlled by fuel humidity above a given threshold of dryness. Thus, fuel humidity control only applies when fire is not limited by other factors such as fuel load, as

15 large fires are virtually absent in dry regions with less than $500 \mathrm{~mm}$ of average annual rainfall, i.e. where fuel amount is insufficient. In regions with sufficient fuel, other factors such as fire suppression or fuel discontinuity can impede large fires even under very dry weather conditions. These findings are relevant under current climatic trends in which the fire season length, in terms of number of days with DC (drought code) values above the observed thresholds (break points), is increasing in many parts of the Mediterranean, while it is decreasing in Eastern Europe and remains unchanged in Central Europe.

\section{Introduction}

During most of the last two thousand years, climate changes have been echoed by variations in areas affected by fire (Marlon et al., 2008), with intervals of rapid temperature change at $13.9,13.2$, and $11.7 \mathrm{kyr}$ marked by large increases in fire activity

BGD

9, 9065-9089, 2012

\section{Two thresholds determine climatic control of forest-fire size in Europe}

L. Loepfe et al.

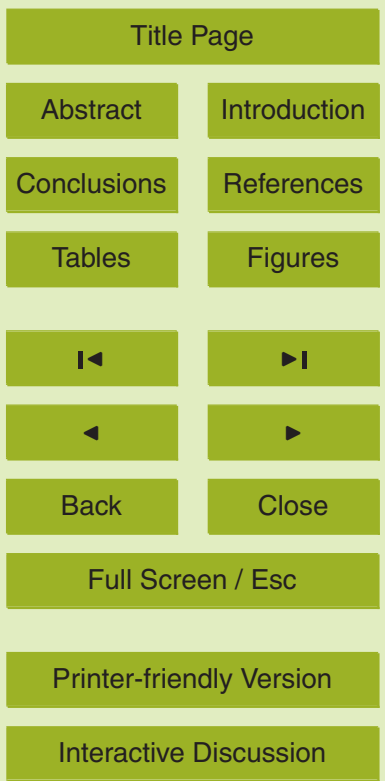


(Marlon et al., 2009). On shorter time scales, many studies have also shown that meteorological indices correlated well with observed fire occurrence (Carvalho et al., 2008, 2010; Meyn et al., 2010; Pausas, 2004; Pausas and Fernández-Muñoz, 2011; Piñol et al., 1998; Trouet et al., 2001). It is therefore reasonable to assume that the ongoing 5 climate change will produce important changes in fire regimes in man regions. Accordingly, it can be expect that a warmer and drier climate will result in increased forest fire activity (e.g. Brown et al., 2004; Carvalho et al., 2011; Flannigan et al., 2000; Williams et al., 2001).

Extrapolations of past weather-fire relationships are widely used to predict fire risk 10 under future weather condition projections (Bergeron et al., 2004; Brown et al., 2004; Carvalho et al., 2008, 2010; Flannigan et al., 2000, 2005; Stocks et al., 1998; Williams et al., 2001). Many studies typically fit monotonically increasing functions, generally using linear or exponential response types, although non-linear, but continuous, approaches to calculate occurrence probability of large fires have also been used 15 (Preisler et al., 2008, 2011; Preisler and Westerling, 2007; Westerling and Bryant, 2008; Westerling et al., 2011). Nevertheless, theoretical studies (Pueyo, 2007) and local empirical analysis (Slocum et al., 2010; Turner and Romme, 1994) reveal a threshold of fuel dryness; as long as this threshold is not crossed, the water content means that large fires are very unlikely to occur. However, these results need to be generalized on broader spatial and high-resolution temporal scales. Furthermore, a second non-linearity - involving another threshold or breakpoint - could occur in the upper range of the fuel dryness gradient, where warmer and drier weather conditions could correspond to dry regions (such as the southernmost part of the Mediterranean region) with lower biomass, that is fuel-load, and continuity (Bachelet et al., 2000; Lenihan et al., 2003), resulting in smaller fires. Although these considerations are crucial to predictions of future fire regimes, detailed, large-scale tests on the relationship between daily weather conditions and fire extent have been lacking to date, mainly due to the previous unavailability of long-term and wide-range data sets. This problem has been
BGD

9, 9065-9089, 2012

\section{Two thresholds determine climatic control of forest-fire size in Europe}

L. Loepfe et al.

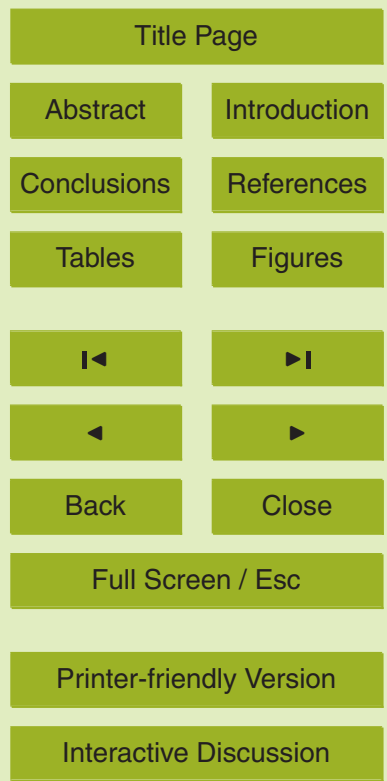


drastically reduced with the appearance of reliable satellite-based observation of fires (Chuvieco, 2008).

Here we present a wide-range statistical analysis of the effects of fuel dryness, daily estimated from meteorological index (Drought Code of the Canadian Fire Weather In-

5 dex), on fire size with high temporal (daily) and spatial $\left(0.25^{\circ}\right)$ resolution for the whole of Europe and North Africa over the years 2001-2010. This regional analysis allows us to differentiate between the direct effects of fuel dryness, estimated on a daily scale, and those related to fuel amount, which correlate to total annual rainfall. We focus our analysis on fire size rather than fire number, since fire extent is the crucial factor in 10 the calculation of total burnt area, as most of the burnt area results from a few very large fires. The region under study presents a wide variety of climatic conditions and fire regimes, which, along with the exceptional availability of its data, makes it an ideal study area. The climate ranges from near desert to Arctic, and so the region embraces fire regimes potentially limited by fuel amount and fuel dryness as well as a wide range 15 of intermediate situations, making the results of this study easily generalizable at continental or global scale.

\section{Material and methods}

\subsection{Fire data source}

Fire data was obtained from the MODIS Active Fire Product (Justice et al., 2002), which provides hotspots, i.e. fire pixels, from mid-infrared radiation related to temperature estimaties. This product correlates better with fire inventories based on groundobservation than other fire products based on satellite-observation and has very little comission errors (Loepfe et al., 2012). We used only data from the Terra satellite, ensuring a consistent data set for the period 2001-2010. Hotspots were grouped into fires using a propagation algorithm. All hotspots that could be connected via a chain of steps of no more than $11 \mathrm{~km}$ and 1 day of difference were considered to belong to the same

\section{BGD}

9, 9065-9089, 2012

\section{Two thresholds determine climatic control of forest-fire size in Europe}

L. Loepfe et al.

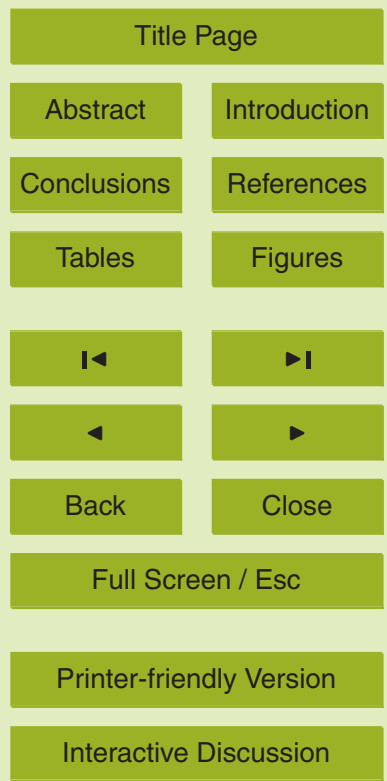


fire. To determine the search radius in the grouping algorithm we individually matched the algorithm-derived fire surfaces (number of hotspots) to ground-observation fires. For this comparison we chose a country, Portugal, with reliable statistics and covering. The coincidence between algorithm-derived fire surfaces and ground-observed 5 fire area was satisfactory $\left(r^{2}=0.60\right.$, Fig. 1$)$, and increased $\left(r^{2}=0.70\right)$ when considering only fires with 10 or more hotspots, revealing that most of the unexplained variance resulted from small fires. Moreover, the results of our analysis were not sensitive to search radius.

We filtered out all hotspots located on pixels classified as urban, crop land or wa10 ter bodies by the IGBP land cover classification map (Belward et al., 1999; Scepan, 1999) obtained from the MODIS MOD12 Land Cover Product (http://www-modis.bu. edu/landcover/userguidelc/lc.html). Previous analysis (Loepfe et al., 2012) showed that filtering out these hotspots greatly increases coincidence of the MODIS Active Fire Product and independent fire inventories. All fires that had five or more neighbour fires within $0.5 \mathrm{~km}$ during the studied time span were excluded, as they are most likely produced by industrial gas flares. In fact, a wildfire frequency of less than two years is unheard in Europe (FAO, 2007). Furthermore, only fires that consisted of at least 2 hotspots were considered to reduce the number of "false positives". The final number of fires included in the models was 13897.

\subsection{Drought code}

Fuel dryness was expressed with the drought code (DC) of the Canadian Fire Weather Index (FWI, Van Wagner and Pickett, 1985), which was developed to depict the water content of deep, compact organic layers and large log, but has also been demonstrated to effectively describe live-fuel humidity measured in the field (Pellizzaro et al., 2007; 25 Viegas et al., 2001). For each day the DC was calculated from the previous day's DC, maximum temperature and rainfall. Temperature and rainfall data were obtained from the E-OBS gridded data set, version 4.0 (Haylock et al., 2008). For temperature data, gap filled was done by averaging the first values available before and after the missing

\section{BGD}

9, 9065-9089, 2012

\section{Two thresholds determine climatic control of forest-fire size in Europe}

L. Loepfe et al.

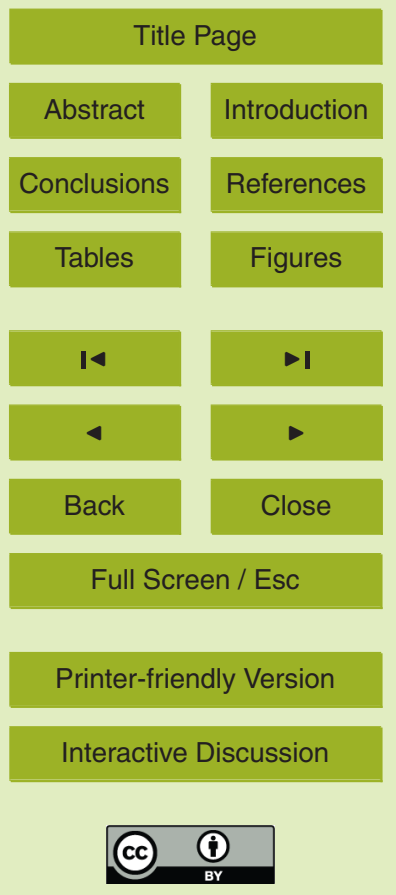


data. For precipitation data, gaps were filled using data of the NCEP-DEO 2 Reanalysis (Kanamitsu et al., 2002). Fires that had a data gap of these climatic parameters up to a month before fire occurrence were not considered in the analysis. For the calculations of yearly accumulated rainfall over 1951-2010 and fire season length, when no NCEP5 DEO was available (years before 1979), gaps in the E-OBS data were filled with zero rainfall, as these gaps were situated mostly in the dry areas of Northern Africa.

\subsection{Statistical analysis}

Fire size was predicted from daily drought codes (DC) using Generalized Additive Models (GAM) and segmented Generalized Linear Models (GLM), assuming in all cases a negative binomial error distribution and a logarithmic link function. The smooth curves resulting from GAMs results in superior fits, however they may be hard to interpret, and overfitting can be a problem. A segmented GLM consists of $d$ segments and $d-1$ breakpoints dividing them. Within each segment a linear function is fitted. Breakpoints were assumed to be continuous, implying that each segment can have a different slope, but there is only one overall interception. All calculations were done in $\mathrm{R}$ (http://www.R-project.org). GAMs were resolved using the mgcv-package (Wood, 2000), GLMs with the MASS-package (Venables and Ripley, 2002). Change-points were included in the design-matrix as done in Hofrichter (2007). We performed a gridsearch to localize the change-points that gave the highest maximum likelihood. Models with zero, one, two, three and four change-points were performed and compared using Bayesian Information Criterion (BIC). Each change-point contributed with two additional parameters, one for slope and one for location. Our hypotheses about the existence of two thresholds would be best confirmed with a triple-segmented model (i.e. two change-points), being the slopes near zero in the first and third segment and 25 steep in the middle segment, which would be equivalent to a "ramp" model (Mudelsee, 2000). One the other hand, lowest BIC obtained in the non-segmented model would reject the hypothesis of non-linearity.
BGD

9, 9065-9089, 2012

\section{Two thresholds determine climatic control of forest-fire size in Europe}

L. Loepfe et al.

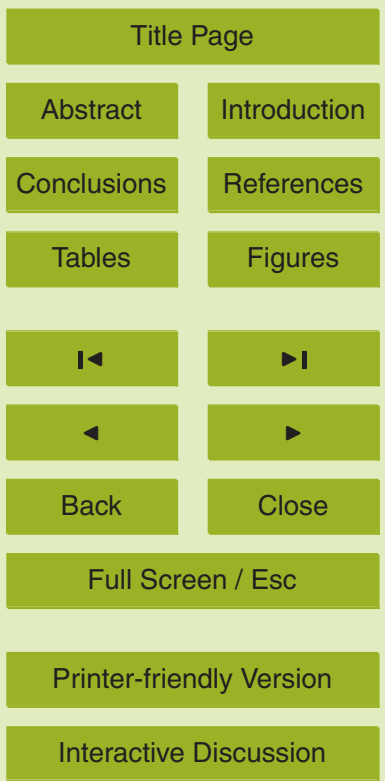


In this study we focus on fire size, being minor the contribution of small fires to total burnt area. However, fire size-frequency distribution is highly over-dispersed, as it results from a large amount of fires that remain small. We found that this distribution is best described with a power law (Fig. A1), in agreement with studies for the United 5 States (Malamud et al., 2005) and the Mediterranean Basin (Ricotta et al., 1999). Power law distributions are scale-free, i.e. they do not have a mean value. To overcome this problem, we divided the observed range of DC into 50 even-sized intervals and considered only the $5 \%$ largest fires within each interval. Despite these statistical shortcomings, we performed the analysis of the whole set of fires, as it still gives o important qualitative insights.

Average yearly accumulated rainfall over the period 1951-2010 was used as a proxy of fuel amount as water availability limits plant growth on a regional scale (Knapp and Smith, 2001; Lieth, 1975; Rosenzweig, 1968; Sala et al., 1988; Webb et al., 1983). We divided pixels into three categories corresponding to bioclimatic regions: dry $(<500 \mathrm{~mm}$ of average yearly rainfall), intermediate $(500-800 \mathrm{~mm}$ ) and humid ( $>800 \mathrm{~mm})$.

We classified each pixel-day according to its DC-value position in the ramp function consisting on different segments determined by the breakpoints. We define fire-season length as the number of days per year in which large fires occur in the segments. We counted the number of pixel-days in each three segment category of the ramp function, comparing the period 1991-2010 to the period 1951-1970.

\section{Results}

Fire size showed a clearly non-linear response to fuel humidity determined by several breakpoints, both when considering all fires and when considering only the largest $5 \%$ of fires from 50 evenly spaced DC intervals (Fig. 2). According to a ramp function shape 25 (Mudelsee, 2000), three main segments were found. The first segment - named "safe" - occurs below DC values of approximately 320 - corresponding to low fuel humidity - where large fires are very unlikely. Within that segment two additional sub-phases

\section{BGD}

9, 9065-9089, 2012

\section{Two thresholds determine climatic control of forest-fire size in Europe}

L. Loepfe et al.

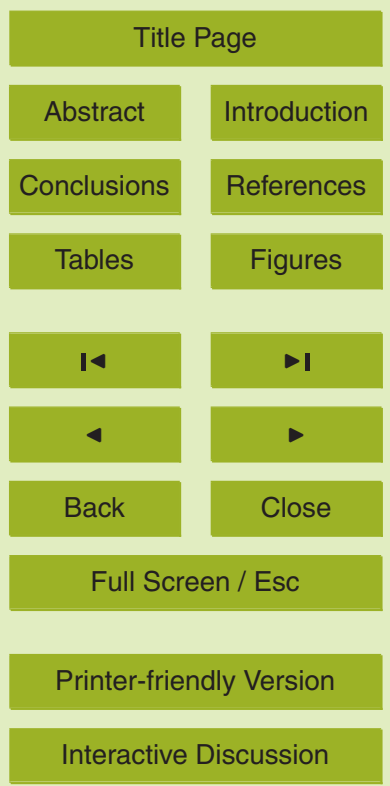


were detected: below DC values of 200 , there is a minor increase in fire size in relation to fuel dryness, while above this value fire extent shows a slight decrease (note that Fig. 2 is plotted on a logarithmic scale). The next segment - named "transition" - ranges between DC values of 320 and 620 , and is characterized by an exponen5 tial increase in fire size. The last segment - named "saturation" - corresponds to DC values above 620 , where no further increase in fire size is observed. In the case of the largest (upper percentile) fires, there is even a significant drop within this segment above values of 1220 . This description of the relationship between fire size and fuel dryness is supported by the lowest BIC obtained for models with three breakpoints, 10 when considering all fires, and with four breakpoints, when considering the largest (upper percentile, $5 \%$ ) fires. In any case, similar response patterns and BIC values were obtained for all segmented models, in contrast to the much higher BIC values obtained by applying monotonic exponential fitting (Table 1 ).

The explained deviance increased greatly when we only considered the upper per15 centile fires instead of all fires (Table 1). Note that many fires remain small even under very dry conditions. The response curve of fire size to DC was much flatter and more regular for sites belonging to the driest bioclimatic region than for intermediate and humid sites (Fig. 4). The largest fires occurred on humid sites with values of DC between 600 and 1100, approximately (Figs. 3 and 4). Very few large fires were observed for dry sites (yearly rainfall $<500 \mathrm{~mm}$ ) and values of DC below 600 .

Fire season length, expressed as the number of days in the transition (DC 320620 ) and saturation (DC > 620) segments in the period 1991-2010, was longest in the Mediterranean, around the Black Sea and, to a lesser extent, in parts of Poland (Fig. 5). For the whole of Europe in the same period, $66.1 \%$ of all pixel-days were in the safe segment, $26.3 \%$ in the transition segment, and $7.5 \%$ in the saturation segment. On average, the safe segment lasted 241 days at year, the transition lasted 96 days and the saturation lasted 28 days. Compared to 1951-1971, modelled fire season length has increased in most of Italy and Greece, the Central Iberian Peninsula, the Baltic states, United Kingdom and Ireland, while it has decreased in Eastern Europe, Scandinavia,

\section{BGD}

9, 9065-9089, 2012

\section{Two thresholds determine climatic control of forest-fire size in Europe}

L. Loepfe et al.

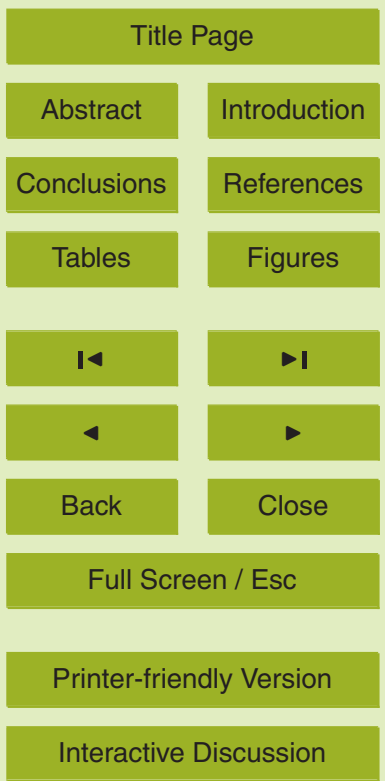


the South-East and Northwest Iberian Peninsula and Turkey (Fig. 5). For the whole of Europe, the average number of days in the safe segment during the period 1991-2010 increased by 22 days, whereas in the transition segment it decreased by 17 days and in the saturation segment it decreased by 5 days.

\section{Discussion}

This large-scale study with great spatial and temporal resolution demonstrates that the monotonically increasing functions commonly used do not completely describe the relationship between fuel dryness and wildfire size at continental scale. Here we provide a statistical tool that unifies the idea of continuous increase in fire risk with dryness 10 (e.g. Brown et al., 2004; Carvalho et al., 2008, 2010; Flannigan et al., 2000, 2005; Stocks et al., 1998; Williams et al., 2001) and the existence of thresholds, i.e. rapid increase in fire size above a given DC value (Pueyo, 2007; Slocum et al., 2010; Turner and Romme, 1994). Overall, our analysis confirms the non-linear response of fire activity to weather conditions that has been reported at coarser resolutions (Krawchuk 15 et al., 2009). In fact, our approach is conceptually equivalent to the "ramp" fitting proposed by Mudelsee (2000) and used for predictions of fire time series (Girardin and Mudelsee, 2008). However, in our approach GAMs and segmented GLMs allow for non-zero slopes in all segments and additional or fewer change-points, whereas in a ramp function, the number of breakpoints (two) and the slope in the first and third segment (zero) have to be preset.

Fire propagation is in fact a binary process, occurring when enough heat is provided to overcome activation energy; if this is not the case, fire is extinguished. This suggests that there is a narrow range of fuel water content that makes fire propagation either inevitable or impossible. All grid-based fire landscape models are based on the assumption of a propagation threshold (e.g. Keane et al., 2006; Li, 2000; Loepfe et al., 2011; Perera, 2008; Sturtevant et al., 2009). Analogously, Bradstock (2010) introduced the concept of "switches" than have to be turned on simultaneously to induce fires, with

\section{BGD}

9, 9065-9089, 2012

\section{Two thresholds determine climatic control of forest-fire size in Europe}

L. Loepfe et al.

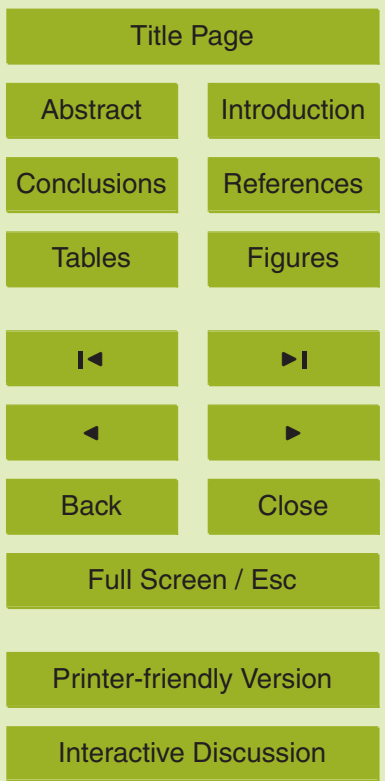


sufficiently low fuel humidity being one of them, as has been supported by empirical results (Krawchuk and Moritz, 2011).

Nevertheless, under real conditions, this propagation threshold is dependent on many other factors, such as wind speed or slope (Weise et al., 2005). This thresh5 old could not, therefore, be pinned down to a single value, but would correspond to a relatively narrow interval of steep increase in the probability of propagation with fuel dryness (Figs. 2, 4). This can be expressed by the mentioned "ramp" function, where the safe phase and the saturation phase are separated not by a single value but by a transition segment with a steep increase in fire size.

10 We considered the safe segment when large fires are virtually absent, corresponding to DC values below approximately 320 (Figs. 2-4). According to the "switches" concept (Bradstock, 2010), at this stage the fuel-availability switch would be turned off: even if other conditions (such as wind and topography) were favourable, fires would not become large. This segment is not homogeneous in our case, however. The initial small 15 increase in fire size observed when DC are below approximately 200 is consistent with the cross-scale-theory (Peters et al., 2004; Slocum et al., 2010), which recognizes "within- and between-patch" thresholds: within-patch drivers allow fires to spread after ignition but further spread is only possible when between-patch drivers are favourable. Above this DC value, fuel dryness would trigger the "within-patch" threshold. So, the large increase in fire size between DC-values of 320-620 could be related to a threshold allowing "between-patch" propagation. In most of Europe, the majority of days fall within the safe segment (Figs. 3 and 5), showing the overall importance of fuel dryness as a factor limiting fire extent. It is worth noting that a significant proportion of the largest fires occurred in rainy localities during the few days with a sufficiently high DC

25 (Fig. 3), showing the importance of the concomitance of fuel amount (estimated from annual precipitation) and fuel dryness in explaining extensive fires.

The general expectation is that increasing temperatures and more frequent drought episodes may result in increasing fire occurrence (Brown et al., 2004; Carvalho et al., 2011; Flannigan et al., 2000; Williams et al., 2001). Nevertheless, climate change might

\section{Two thresholds determine climatic control of forest-fire size in Europe}

L. Loepfe et al.

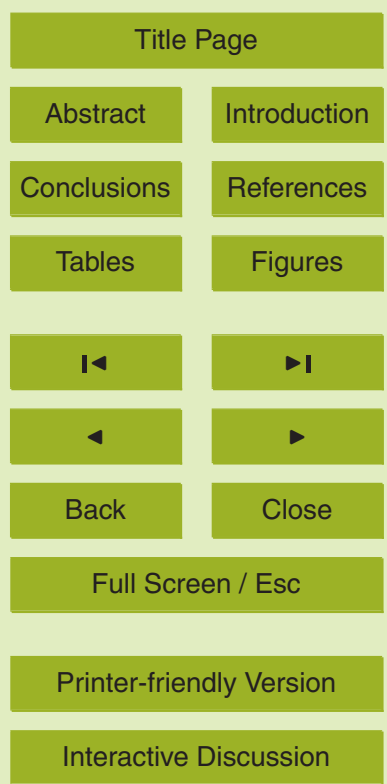


reduce burnt area in some regions (Bachelet et al., 2000; Krawchuk et al., 2009; Lenihan et al., 2003) as a result of a negative correlation between drought occurrence and biomass accumulation. The detailed resolution of our study allows to distinguish between the direct effects of fuel dryness on a daily scale and the indirect effects of 5 biomass load (correlated with yearly rainfall). Thus, our results show that drier weather conditions beyond a certain point (i.e., the saturation segment, DC >620) of fuel dryness do not propitiate any further increase in fire size (Fig. 4). This occurs even on humid sites where biomass amount does not provide any limitation. This has important implications when estimating the impact of climate change on fire regime since 10 the usual linear extrapolations (e.g. Carvalho et al., 2010; Flannigan et al., 2000) can lead to gross overestimation of the future burnt area, especially if the fittings obtained with DC values corresponding to the transition segment are projected beyond the saturation threshold. Note, however, that no climate change scenarios have been tested in this study; therefore the fire size response found with GAMs and segmented GLM 15 on past data is a qualitative indicator, not a predictor of future fire regimes. Nevertheless, our finding agrees with global simulations of future fire regime that point to an increase of the probability of future fires in Central Europe, while in Southern Europe the increasing fire-climatic risk would be counterbalanced by lower moisture probability of fire occurrence (Krawchuk et al., 2009; Kloster et al., 2012).

As the "fuel-humidity" switch is turned on with high DC values - in our case about 620 - other factors, such as biomass amount, fire weather and ignition (Bradstock, 2010; Keeley et al., 1999), fire suppression and fuel continuity (Bajocco and Ricotta, 2008; Lloret et al., 2002; Loepfe et al., 2010) would control the extent of fires. This also explains the significant increase in deviance when considering only the fires of the upper size percentile and when analyzing all fires (see Table 1). In other words, under the conditions of this segment, fuel dryness is a necessary condition for large fires but is not in itself conclusive.

The role of factors other than fuel dryness in controlling fire extent is also revealed by the overall drop in fire size with DC values above approximately 1220 (Fig. 2). This

\section{BGD}

9, 9065-9089, 2012

\section{Two thresholds determine climatic control of forest-fire size in Europe}

L. Loepfe et al.

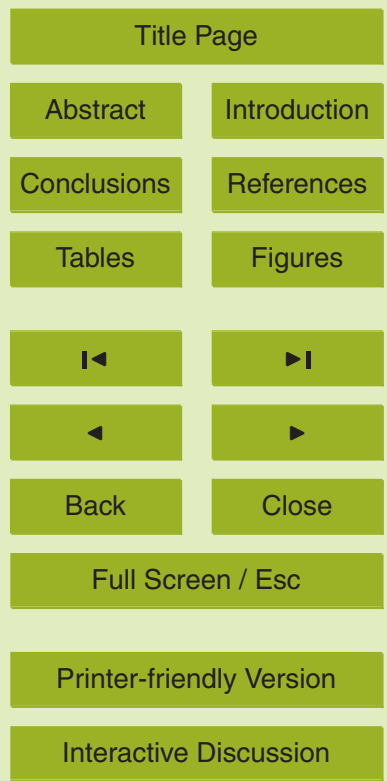


decrease suggests that on drier sites suffering from such extreme DC values, fire extent would be limited by biomass amount. In fact, most large fires occur on sites that do not present extreme low DC values, that is, they likely sustain large amounts of biomass, and they are rarely found on sites with less than $500 \mathrm{~mm}$ of annual rainfall, i.e. they have 5 the "fuel-amount-switch" turned off (Figs. 3 and 4). Nevertheless, a drop in fire size at high DC values is observed in all three rainfall categories. The most likely explanation for this is of a statistical nature. Overall, there are fewer days with high DC (Fig. 3) and consequently there are fewer fires (Fig. 4). As fire size frequency distribution follows a (truncated) power law (Fig. A1), the chance of at least one big fire is lower.

The near-zero slopes in the "safe" and "saturation" phases suggest that climate change will have little impact on burnt area in many areas. In fact, we observe for the whole European territory that the number of days in the safe segment has increased in the last decades, mainly due to higher rainfall in Eastern Europe. Nevertheless, in some regions that have suffered little fire impact up to now, climate change may be 15 leading fuel dryness to the first threshold, possibly resulting on sudden large fires if dry conditions combine with a large amount of biomass (Pueyo, 2007). This would mainly affect areas adjacent to regions with high fire regime, as observed in some parts of the Western United States (Westerling et al., 2006), Amazonian rainforest (Pueyo et al., 2010), NE Spain (Loepfe et al., 2012) and Northern Greece (Dimitrakopoulos et al.,

\section{in the regions covered by our data (Fig. 5).}

The longstanding debate whether and where fuel dryness (as opposed to fuel amount) is limiting fire extent has important management implications. Whereas fire suppression would effectively reduce the total burnt area (Moritz et al., 2004; Mouillot and Field, 2005) in moist ecosystems where fuel dryness limits wildfires, fire suppression may prove inefficient or even counter-productive in drier ecosystems where fuel amount limits wildfires, as the resulting fuel accumulation leads to bigger fires in the future (Minnich, 1983; Piñol et al., 2005, 2007). So, an increased effort to suppress fire, which could compensate for a higher human-induced ignition frequency (Keeley

\section{BGD}

9, 9065-9089, 2012

\section{Two thresholds determine climatic control of forest-fire size in Europe}

L. Loepfe et al.

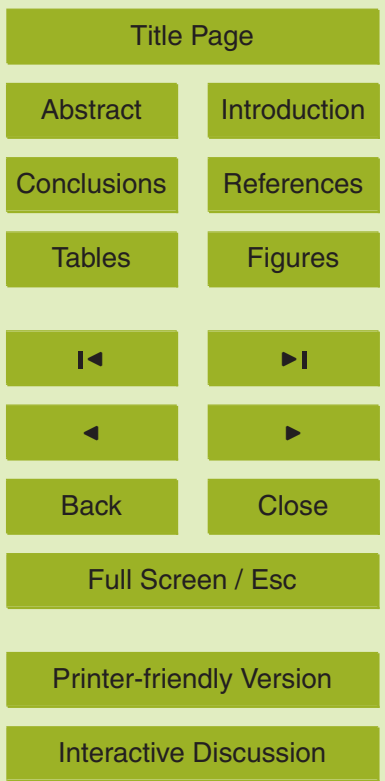


et al., 1999), would make sense, especially in high biomass areas that suffer from few days of elevated fuel dryness. Under such conditions, fires that escape initial control can grow extensively without essentially reducing the risk of future fires since biomass is expected to accumulate rapidly after fire. Also, a fuel reduction that would slightly 5 increase the thresholds for effective fire fighting (Fernandes and Botelho, 2003) could result in a significant reduction in burnt area.

Acknowledgements. This study was supported by the Spanish Ministry of Science and Innovation (project MONTES, Consolider-Ingenio 2010) and the Generalitat de Catalunya (AGAUR, SGR2009-247).

\section{References}

Bachelet, D., Lenihan, J. M., Daly, C., and Neilson, R. P.: Interactions between fire, grazing and climate change at Wind Cave National Park, SD, Ecol. Model., 134, 229-244, 2000.

Bajocco, S. and Ricotta, C.: Evidence of selective burning in Sardinia (Italy): which land-cover classes do wildfires prefer?, Landscape Ecol., 23, 241-248, 2008.

15 Belward, A. S., Estes, J. E., and Kline, K. D.: The IGBP-DIS global 1-km landcover data set discover - a project overview, Photogram. Eng. Remote Sens., 65, 1013-1020, 1999.

Bergeron, Y., Flannigan, M., Gauthier, S., Leduc, A., and Lefort, P.: Past, current and future fire frequency in the Canadian boreal forest: implications for sustainable forest management, AMBIO, 33, 356-360, doi:10.1579/0044-7447-33.6.356, 2004.

Bradstock, R. A.: A biogeographic model of fire regimes in Australia: current and future implications, Global Ecol. Biogeogr., 19, 145-158, 2010.

Brown, T. J., Hall, B. L., and Westerling, A. L.: The impact of twenty-first century climate change on wildland fire danger in the Western United States: an applications perspective, Climatic Change, 62, 365-388, 2004.

25 Carvalho, A., Flannigan, M. D., Logan, K., Miranda, A. I., and Borrego, C.: Fire activity in Portugal and its relationship to weather and the Canadian fire weather index system, Int. J. Wildland Fire, 17, 328-338, 2008.
BGD

9, 9065-9089, 2012

\section{Two thresholds determine climatic control of forest-fire size in Europe}

L. Loepfe et al.

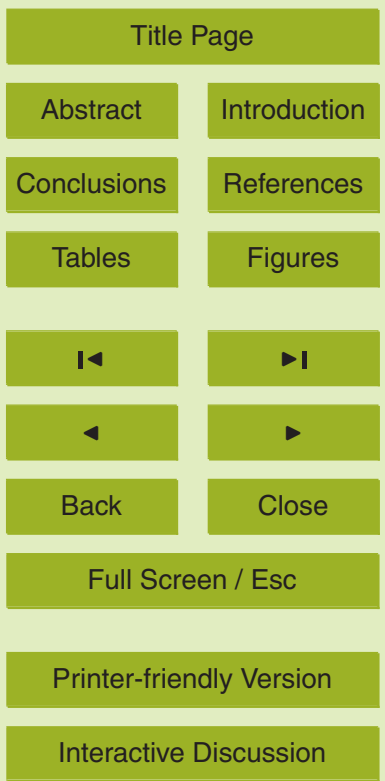


Carvalho, A., Flannigan, M., Logan, K., Gowman, L., Miranda, A., and Borrego, C.: The impact of spatial resolution on area burned and fire occurrence projections in Portugal under climate change, Climatic Change, 98, 177-197, 2010.

Carvalho, A. C., Carvalho, A., Martins, H., Marques, C., Rocha, A., Borrego, C., Viegas, D. X., 5 and Miranda, A. I.: Fire weather risk assessment under climate change using a dynamical downscaling approach, Environ. Model. Softw., 26, 1123-1133, 2011.

Chuvieco, E. (Ed.): Satellite observation of biomass burning, in: Earth Observation of Global Change, Springer, Netherlands, 109-142, doi:10.1029/2008JD010201, 2008.

Dimitrakopoulos, A., Vlahou, M., Anagnostopoulou, C., and Mitsopoulos, I.: Impact of drought on wildland fires in Greece: implications of climatic change?, Climatic Change, 109, 331347, 2011.

FAO: Fire management global assessment, 2006, Food and Agriculture Organization of the United Nations, Rome, 2007.

Fernandes, P. M. and Botelho, H. S.: A review of prescribed burning effectiveness in fire hazard reduction, Int. J. Wildland Fire, 12, 117-128, 2003.

Flannigan, M. D., Logan, K., Amiro, B., Skinner, W., and Stocks, B. J.: Future area burned in Canada, Climatic Change, 72, 1-16, 2005.

Flannigan, M. D., Stocks, B. J., and Wotton, B. M.: Climate change and forest fires, Sci. Total Environ., 262, 221-229, 2000.

Girardin, M. P. and Mudelsee, M.: Past and future changes in Canadian boreal wildfire activity, Ecol. Appl., 18, 391-406, 2008.

Haylock, M. R., Hofstra, N., Klein Tank, A. M. G., Klok, E. J., Jones, P. D. and New, M.: A European daily high-resolution gridded data set of surface temperature and precipitation for 1950-2006, J. Geophys. Res., 113, D20119, doi:10.1029/2008JD010201, 2008.

Hofrichter, J.: Change Point Detection in Generalized Linear Models, master thesis, Technische Universität Graz, Graz, 2007.

Justice, C. O., Giglio, L., Korontzi, S., Owens, J., Morisette, J. T., Roy, D., Descloitres, J., Alleaume, S., Petitcolin, F., and Kaufman, Y.: The MODIS fire products, Remote Sens. Environ., 83, 244-262, 2002.

so Kanamitsu, M., Kumar, A., Juang, H.-H., Schemm, J., Wang, W., Yang, F., Hong, S. Y., Peng, P., Chen, W., Moorthi, S., and Ji, M.: NCEP dynamical seasonal forecast system 2000, B. Am. Meteorol. Soc., 83, 1019-1037, 2002.
BGD

9, 9065-9089, 2012

\section{Two thresholds determine climatic control of forest-fire size in Europe}

L. Loepfe et al.

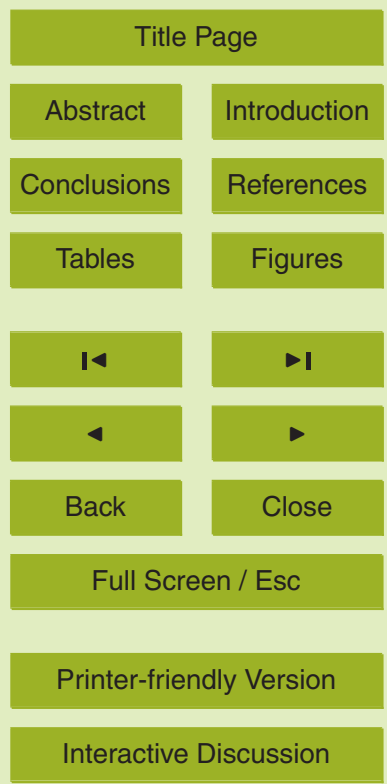


Keane, R. E., Holsinger, L. M., and Pratt, S. D.: Simulating historical landscape dynamics using the landscape fire succession model LANDSUM version 4.0, available at: http://www.fs.fed. us/rm/pubs/rmrs_gtr171.pdf (last access: 21 July 2012), 2006.

Keeley, J. E., Fotheringham, C. J., and Morais, M.: Reexamining fire suppression impacts on brushland fire regimes, Science, 284, 1829-1832, 1999.

Kloster, S., Mahowald, N. M., Randerson, J. T., and Lawrence, P. J.: The impacts of climate, land use, and demography on fires during the 21st century simulated by CLM-CN, Biogeosciences, 9, 509-525, doi:10.5194/bg-9-509-2012, 2012.

Knapp, A. K. and Smith, M. D.: Variation among biomes in temporal dynamics of aboveground primary production, Science, 291, 481-484, 2001.

Krawchuk, M. A. and Moritz, M. A.: Constraints on global fire activity vary across a resource gradient, Ecology, 92, 121-132, 2011.

Krawchuk, M. A., Moritz, M. A., Parisien, M., Van Dorn, J., and Hayhoe, K.: Global pyrogeography: the current and future distribution of wildfire, PLoS ONE, 4, e5102, doi:10.1371/journal.pone.0005102, 2009.

Lenihan, J. M., Drapek, R., Bachelet, D., and Neilson, R. P.: Climate change effects on vegetation distribution, carbon, and fire in California, Ecol. Appl., 13, 1667-1681, 2003.

$\mathrm{Li}, \mathrm{C} .:$ Reconstruction of natural fire regimes through ecological modelling, Ecol. Model., 134, 129-144, 2000.

20 Lieth, H.: Primary Productivity of the Biosphere, Springer, New York, 1975.

Lloret, F., Calvo, E., Pons, X., and Diaz-Delgado, R.: Wildfires and landscape patterns in the Eastern Iberian Peninsula, Landscape Ecol., 17, 745-759, 2002.

Loepfe, L., Martinez-Vilalta, J., Oliveres, J., Piñol, J., and Lloret, F.: Feedbacks between fuel reduction and landscape homogenisation determine fire regimes in three Mediterranean areas,

25 Forest Ecol. Manag., 259, 2366-2374, 2010.

Loepfe, L., Martinez-Vilalta, J., and Piñol, J.: An integrative model of human-influenced fire regimes and landscape dynamics, Environ. Model. Softw., 26, 1028-1040, 2011.

Loepfe, L., Lloret, F., and Román-Cuesta, R. M.: Comparison of burnt area estimates derived from satellite products and national statistics in Europe, Int. J. Remote Sens., 33, 3653-3671, $30 \quad 2012$

Malamud, B. D., Millington, J. D. A., and Perry, G. L. W.: Characterizing wildfire regimes in the United States, Proc. Natl. Acad. Sci., 102, 4694-4699, 2005.

BGD

9, 9065-9089, 2012

\section{Two thresholds determine climatic control of forest-fire size in Europe}

L. Loepfe et al.

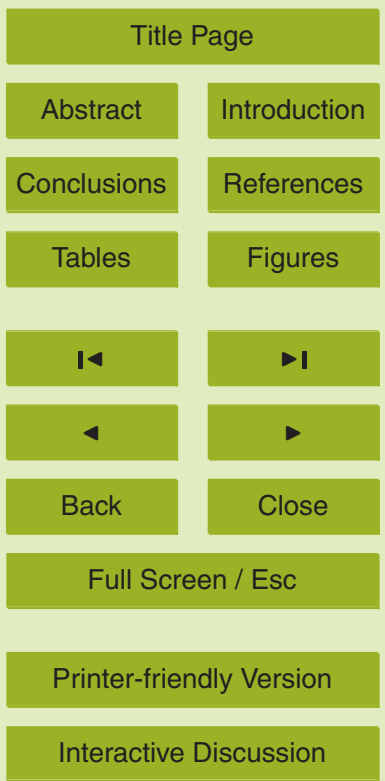


Marlon, J. R., Bartlein, P. J., Carcaillet, C., Gavin, D. G., Harrison, S. P., Higuera, P. E., Joos, F., Power, M. J., and Prentice, I. C.: Climate and human influences on global biomass burning over the past two millennia, Nat. Geosci., 1, 697-702, 2008.

Marlon, J. R., Bartlein, P. J., Walsh, M. K., Harrison, S. P., Brown, K. J., Edwards, M. E., 5 Higuera, P. E., Power, M. J., Anderson, R. S., Briles, C., Brunelle, A., Carcaillet, C., Daniels, M., Hu, F. S., Lavoie, M., Long, C., Minckley, T., Richard, P. J. H., Scott, A. C., Shafer, D. S., Tinner, W., Umbanhowar, C. E., and Whitlock, C.: Wildfire responses to abrupt climate change in North America, Proc. Natl. Acad. Sci., 106, 2519-2524, 2009.

Meyn, A., Schmidtlein, S., Taylor, S. W., Girardin, M. P., Thonicke, K., and Cramer, W.: Spatial variation of trends in wildfire and summer drought in British Columbia, Canada, 1920-2000, Int. J. Wildland Fire, 19, 272-283, 2010.

Minnich, R. A.: Fire mosaics in Southern California and Northern Baja California, Science, 219, 1287-1294, 1983.

Moritz, M. A., Keeley, J. E., Johnson, E. A., and Schaffner, A. A.: Testing a basic assumption 15 of shrubland fire management: how important is fuel age?, Front. Ecol. Environ., 2, 67-72, 2004.

Mouillot, F. and Field, C. B.: Fire history and the global carbon budget: a $1^{\circ} \times 1^{\circ}$ fire history reconstruction for the 20th century, Glob. Change Biol., 11, 398-420, 2005.

Mudelsee, M.: Ramp function regression: a tool for quantifying climate transitions, Comput. Geosci., 26, 293-307, 2000.

Pausas, J. G.: Changes in fire and climate in the Eastern Iberian Peninsula (Mediterranean Basin), Climatic Change, 63, 337-350, 2004.

Pausas, J. G. and Fernández-Muñoz, S.: Fire regime changes in the Western Mediterranean Basin: from fuel-limited to drought-driven fire regime, Climatic Change, 110, 215-226, doi:10.1007/s10584-011-0060-6, 2011.

Pellizzaro, G., Cesaraccio, C., Duce, P., Ventura, A. and Zara, P.: Relationships between seasonal patterns of live fuel moisture and meteorological drought indices for Mediterranean shrubland species, Int. J. Wildland Fire, 16, 232-241, 2007.

Perera, A.: BFOLDS 1.0: a spatial simulation model for exploring large scale fire regimes and succession in boreal forest landscapes, Ontario Forest Research Institute, 2008.

Peters, D. P. C., Pielke, R. A., Bestelmeyer, B. T., Allen, C. D., Munson-McGee, S., and Havstad, K. M.: Cross-scale interactions, nonlinearities, and forecasting catastrophic events, Proc. Natl. Acad. Sci., 101, 15130-15135, 2004.
BGD

9, 9065-9089, 2012

\section{Two thresholds determine climatic control of forest-fire size in Europe}

L. Loepfe et al.

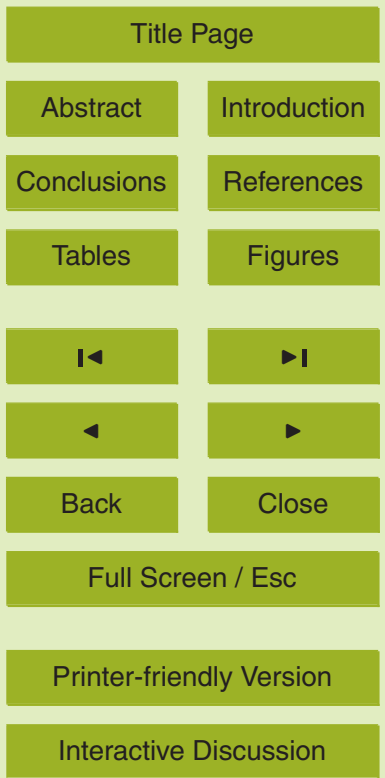


Piñol, J., Beven, K., and Viegas, D. X.: Modelling the effect of fire-exclusion and prescribed fire on wildfire size in Mediterranean ecosystems, Ecol. Model., 183, 397-409, 2005.

Piñol, J., Castellnou, M., and Beven, K. J.: Conditioning uncertainty in ecological models: assessing the impact of fire management strategies, Ecol. Model., 207, 34-44, 2007.

5 Piñol, J., Terradas, J., and Lloret, F.: Climate warming, wildfire hazard, and wildfire occurrence in coastal Eastern Spain, Climatic Change, 38, 345-357, 1998.

Preisler, H. K. and Westerling, A. L.: Statistical model for forecasting monthly large wildfire events in Western United States, J. Appl. Meteorol. Climatol., 46, 1020-1030, 2007.

Preisler, H. K., Chen, S. C., Fujioka, F., Benoit, J. W., and Westerling, A. L.: Meteorological model applications for estimating probabilities of wildland fires, Int. J. Wildland Fire, 17, 305316, 2008.

Preisler, H. K., Westerling, A. L., Gebert, K. M., Munoz-Arriola, F., and Holmes, T. P.: Spatially explicit forecasts of large wildland fire probability and suppression costs for California, Int. J. Wildland Fire, 20, 508-517, 2011.

15 Pueyo, S.: Self-organised criticality and the response of wildland fires to climate change, Climatic Change, 82, 131-161, 2007.

Pueyo, S., De Alencastro Graça, P. M. L., Barbosa, R. I., Cots, R., Cardona, E., and Fearnside, P. M.: Testing for criticality in ecosystem dynamics: the case of Amazonian rainforest and savanna fire, Ecol. Lett., 13, 793-802, 2010.

20 Ricotta, C., Avena, G., and Marchetti, M.: The flaming sandpile: self-organized criticality and wildfires, Ecol. Model., 119, 73-77, 1999.

Rosenzweig, M. L.: Net primary productivity of terrestrial communities: prediction from climatological data, Am. Nat., 102, 67-74, 1968.

Sala, O. E., Parton, W. J., Joyce, L. A., and Lauenroth, W. K.: Primary production of the central grassland region of the United States, Ecology, 69, 40-45, 1988.

Scepan, J.: Thematic validataion of high-resolution global land-cover data sets, Photogram. Eng. Remote Sens., 65, 1051-1060, 1999.

Slocum, M., Beckage, B., Platt, W., Orzell, S., and Taylor, W.: Effect of climate on wildfire size: a cross-scale analysis, Ecosystems, 13, 828-840, 2010.

30 Stocks, B. J., Fosberg, M. A., Lynham, T. J., Mearns, L., Wotton, B. M., Yang, Q., Jin, J., Lawrence, K., Hartley, G. R., Mason, J. A., and McKenney, D. W.: Climate change and forest fire potential in Russian and Canadian boreal forests, Climatic Change, 38, 1-13, 1998.

BGD

9, 9065-9089, 2012

\section{Two thresholds determine climatic control of forest-fire size in Europe}

L. Loepfe et al.

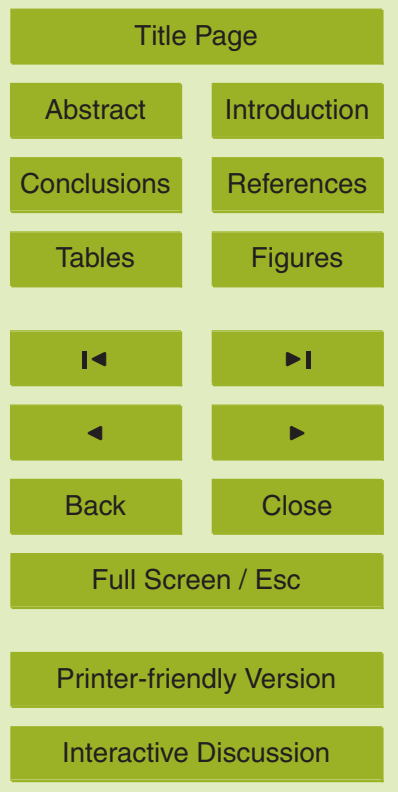


Sturtevant, B. R., Scheller, R. M., Miranda, B. R., Shinneman, D., and Syphard, A.: Simulating dynamic and mixed-severity fire regimes: a process-based fire extension for LANDIS-II, Ecol. Model., 220, 3380-3393, 2009.

Trouet, V., Taylor, A., Carleton, A., and Skinner, C.: Interannual variations in fire weather, fire extent, and synoptic-scale circulation patterns in Northern California and Oregon, Theor. Appl. Climatol., 95, 349-360, 2001.

Turner, M. G. and Romme, W. H.: Landscape dynamics in crown fire ecosystems, Landscape Ecol., 9, 59-77, 1994.

Van Wagner, C. E. and Pickett, T. L.: Equations and FORTRAN program for the Canadian Forest Fire Weather Index System, Canadian Forestry Service, Ottawa, ON, 1985.

Venables, W. N. and Ripley, B. D.: Modern Applied Statistics with S, Springer, 4th Edn., New York, USA, 2002.

Viegas, D. X., Piñol, J., Viegas, M. T., and Ogaya, R.: Estimating live fine fuels moisture content using meteorologically-based indices, Int. J. Wildland Fire, 10, 223-240, 2001.

Webb, W. L., Lauenroth, W. K., Szarek, S. R., and Kinerson, R. S.: Primary production and abiotic controls in forests, grasslands, and desert ecosystems in the United States, Ecology, 64, 134-151, 1983.

Weise, D. R., Zhou, X., Sun, L., and Mahalingam, S.: Fire spread in chaparral - "go or no-go?", Int. J. Wildland Fire, 14, 99-106, 2005.

Westerling, A. and Bryant, B.: Climate change and wildfire in California, Climatic Change, 87, 231-249, 2008.

Westerling, A. L., Hidalgo, H. G., Cayan, D. R., and Swetnam, T. W.: Warming and earlier spring increase Western US forest wildfire activity, Science, 313, 940-943, 2006.

Westerling, A., Bryant, B., Preisler, H., Holmes, T., Hidalgo, H., Das, T. and Shrestha, S.: Climate change and growth scenarios for California wildfire, Climatic Change, 109, 445-463, 2011.

Williams, A. A. J., Karoly, D. J., and Tapper, N.: The sensitivity of Australian fire danger to climate change, Climatic Change, 49, 171-191, 2001.

Wood, S. N.: Modelling and smoothing parameter estimation with multiple quadratic penalties, J. Roy. Stat. Soc. B, 62, 413-428, 2000.

BGD

9, 9065-9089, 2012

\section{Two thresholds determine climatic control of forest-fire size in Europe}

L. Loepfe et al.

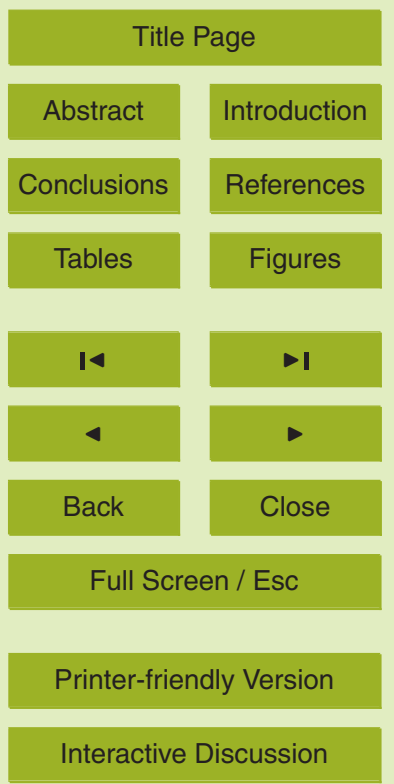




\section{BGD}

9, 9065-9089, 2012

Table 1. Akaike Information Criterion (AIC), Bayesian Information Criterion (BIC), percentage of deviance explained and location of breakpoints for different models considering all fires or only extreme-size fires (the largest $5 \%$ within each of 50 bins over the DC-range).

\begin{tabular}{lllll}
\hline $\begin{array}{l}\text { number of } \\
\text { breakpoints }\end{array}$ & AIC & BIC & $\begin{array}{l}\text { deviation } \\
\text { explained }\end{array}$ & Breakpoints \\
\hline all fires & & & & \\
\hline 0 & 51120 & 51143 & $5.4 \%$ & \\
1 & 50873 & 50903 & $7.4 \%$ & 660 \\
2 & 50845 & 50883 & $7.6 \%$ & 540,620 \\
3 & 50793 & 50839 & $8.0 \%$ & $200,320,620$ \\
4 & 50787 & 50840 & $8.1 \%$ & $200,320,640,680$ \\
GAM & 50792 & 50864 & $8.1 \%$ & \\
\hline extreme fires & & & & \\
\hline 0 & 7058 & 7072 & $21.3 \%$ & \\
1 & 6840 & 6859 & $38.7 \%$ & 920 \\
2 & 6852 & 6876 & $38.0 \%$ & 660,680 \\
3 & 6786 & 6815 & $42.7 \%$ & $200,320,650$ \\
4 & 6755 & 6787 & $44.9 \%$ & $200,320,590,1220$ \\
GAM & 6749 & 6794 & $45.5 \%$ & \\
\hline
\end{tabular}

Two thresholds determine climatic control of forest-fire size in Europe

L. Loepfe et al.

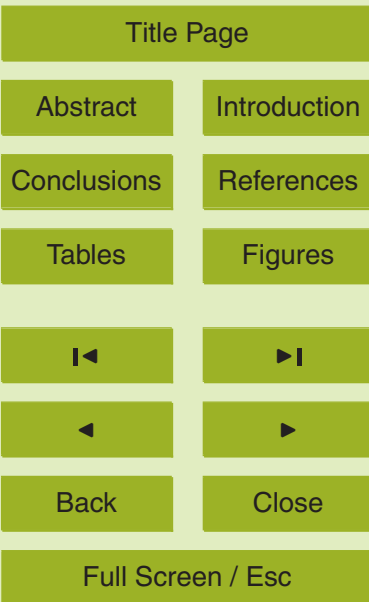

Printer-friendly Version

Interactive Discussion 


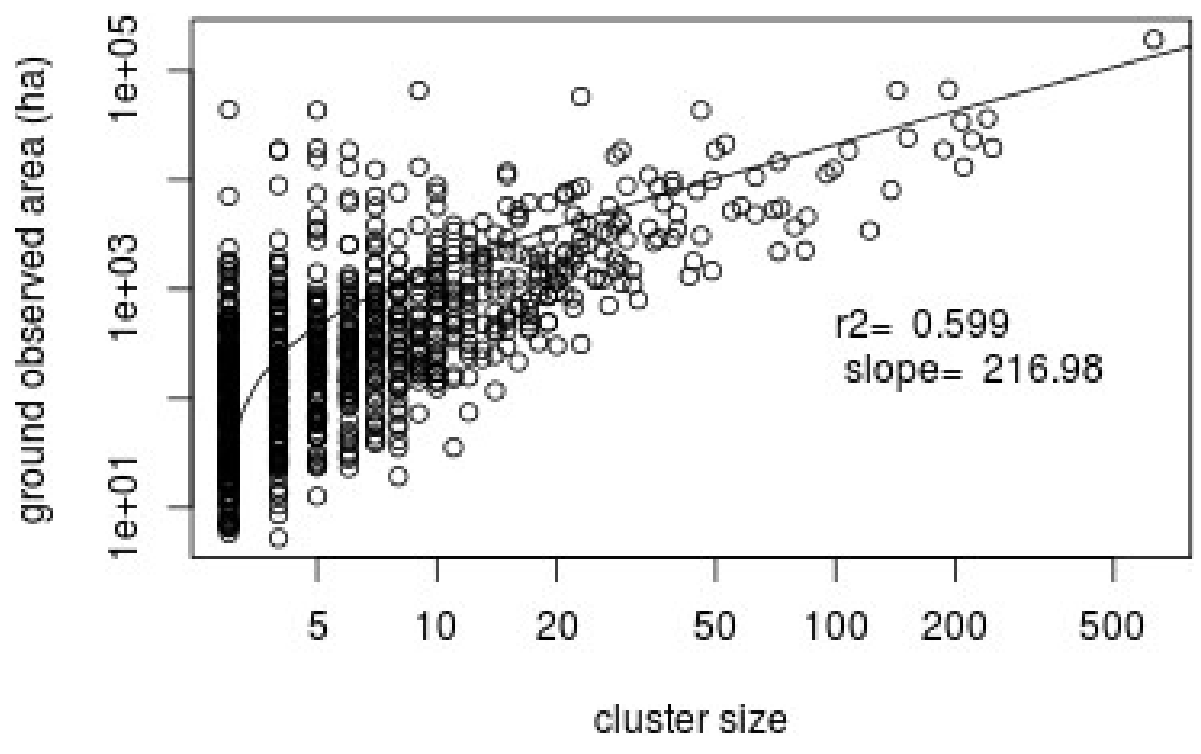

Fig. 1. Relationship between cluster size of agreated hotspots found with a propagation algorithm and ground-observed burned area of Portuguese fires between 2001-2010. Note that the explained variance increases when considering only larger clusters.

\section{BGD}

9, 9065-9089, 2012

\section{Two thresholds determine climatic control of forest-fire size in Europe}

L. Loepfe et al.

\section{Title Page}

Abstract

Introduction

Conclusions

References

Tables

Figures

14

4

Back

Close

Full Screen / Esc

Printer-friendly Version

Interactive Discussion 


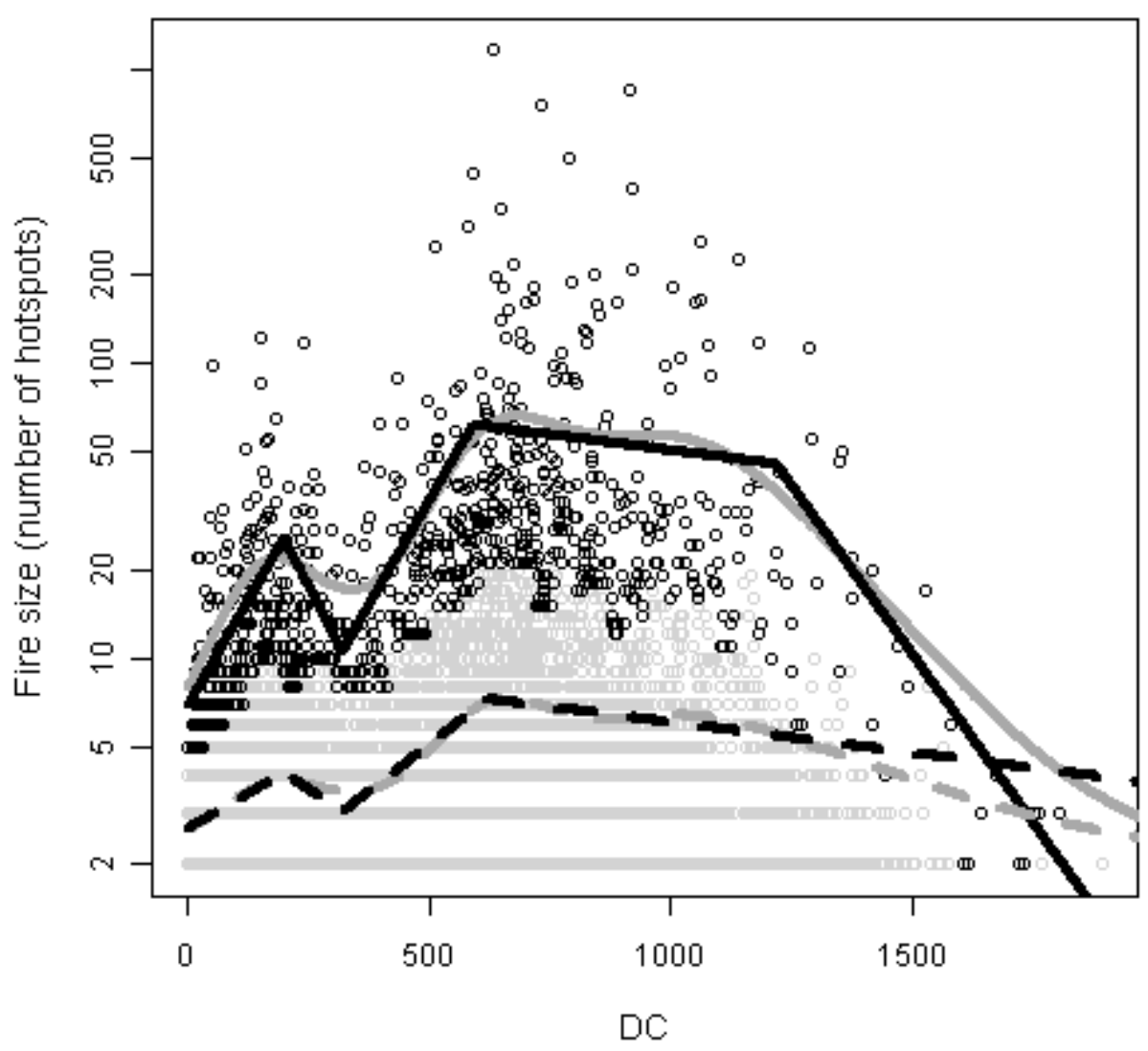

Fig. 2. Fire size response to fuel dryness. Extreme fires, i.e. the largest $5 \%$ within each of 50 bins over the DC (drought code) range, are plotted in black, with the remaining fires in gray. Fittings of a General Additive Model (GAM, gray) and the best (in terms of BIC, see Table 1) segmented model (black) are represented by continuous lines for extreme fires, and by dashed lines for all fires.

\section{BGD}

9, 9065-9089, 2012

\section{Two thresholds determine climatic control of forest-fire size in Europe}

L. Loepfe et al.

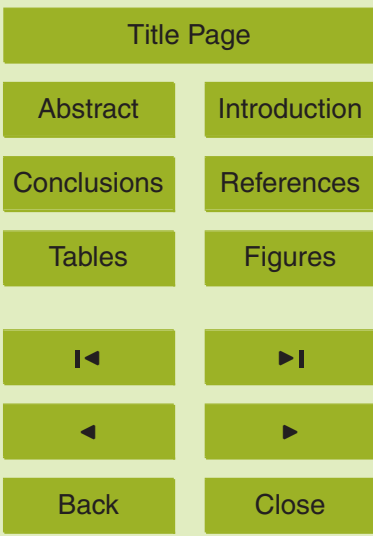

Full Screen / Esc

Printer-friendly Version

Interactive Discussion 


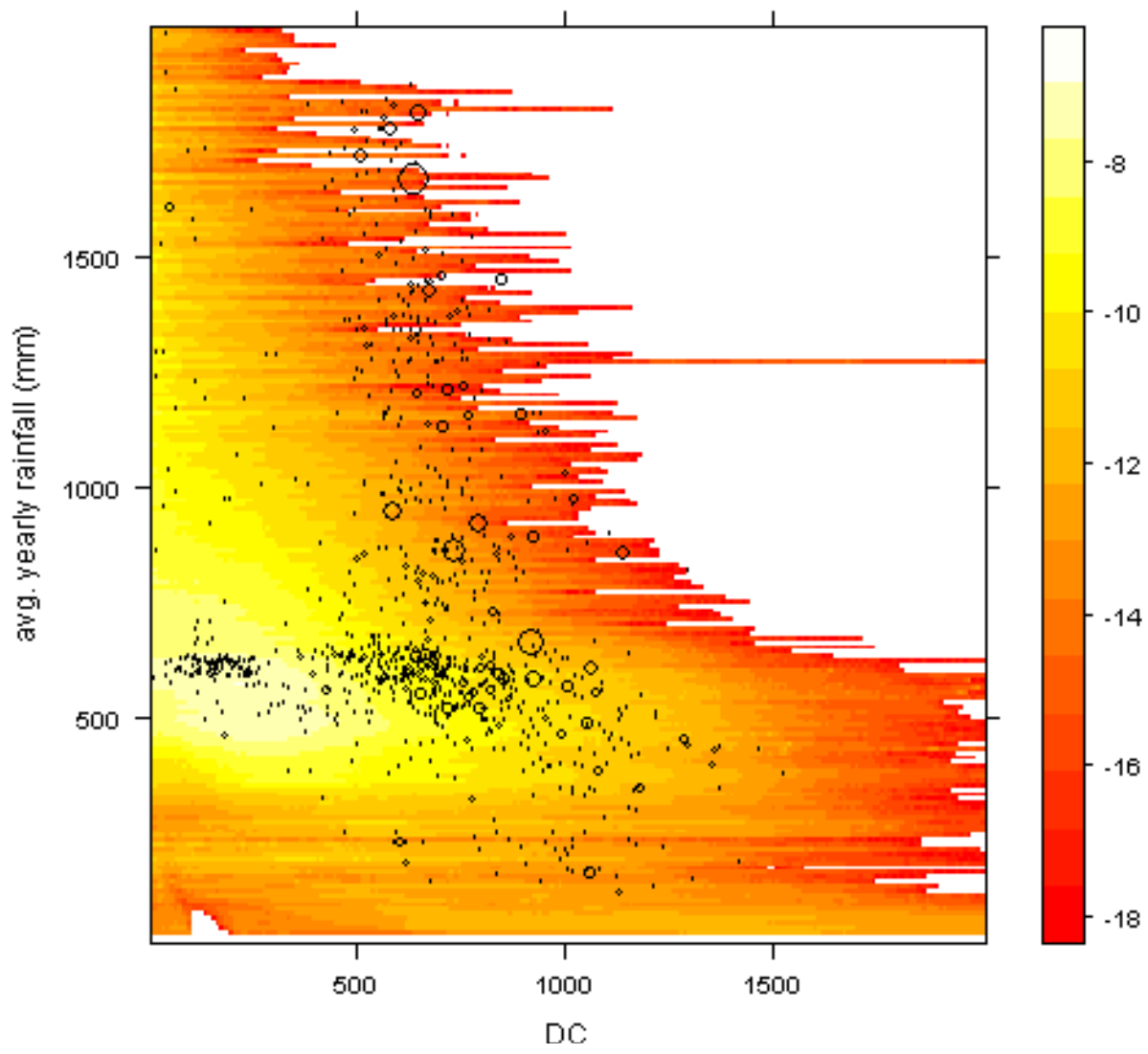

Fig. 3. Relative occurrence of combinations of mean yearly rainfall (1951-2010, estimator of fuel load) and daily DC values. Black circles correspond to fire clusters greater than 10 hotspots, the plotted area being proportional to cluster size. Colour scale indicates the natural logarithm of relative frequency of occurrence.

\section{BGD}

9, 9065-9089, 2012

\section{Two thresholds determine climatic control of forest-fire size in Europe}

L. Loepfe et al.

\section{Title Page}

\section{Abstract}

Introduction

Conclusions

References

Tables

Figures

14

4

Back

\section{Full Screen / Esc}

Printer-friendly Version

Interactive Discussion 


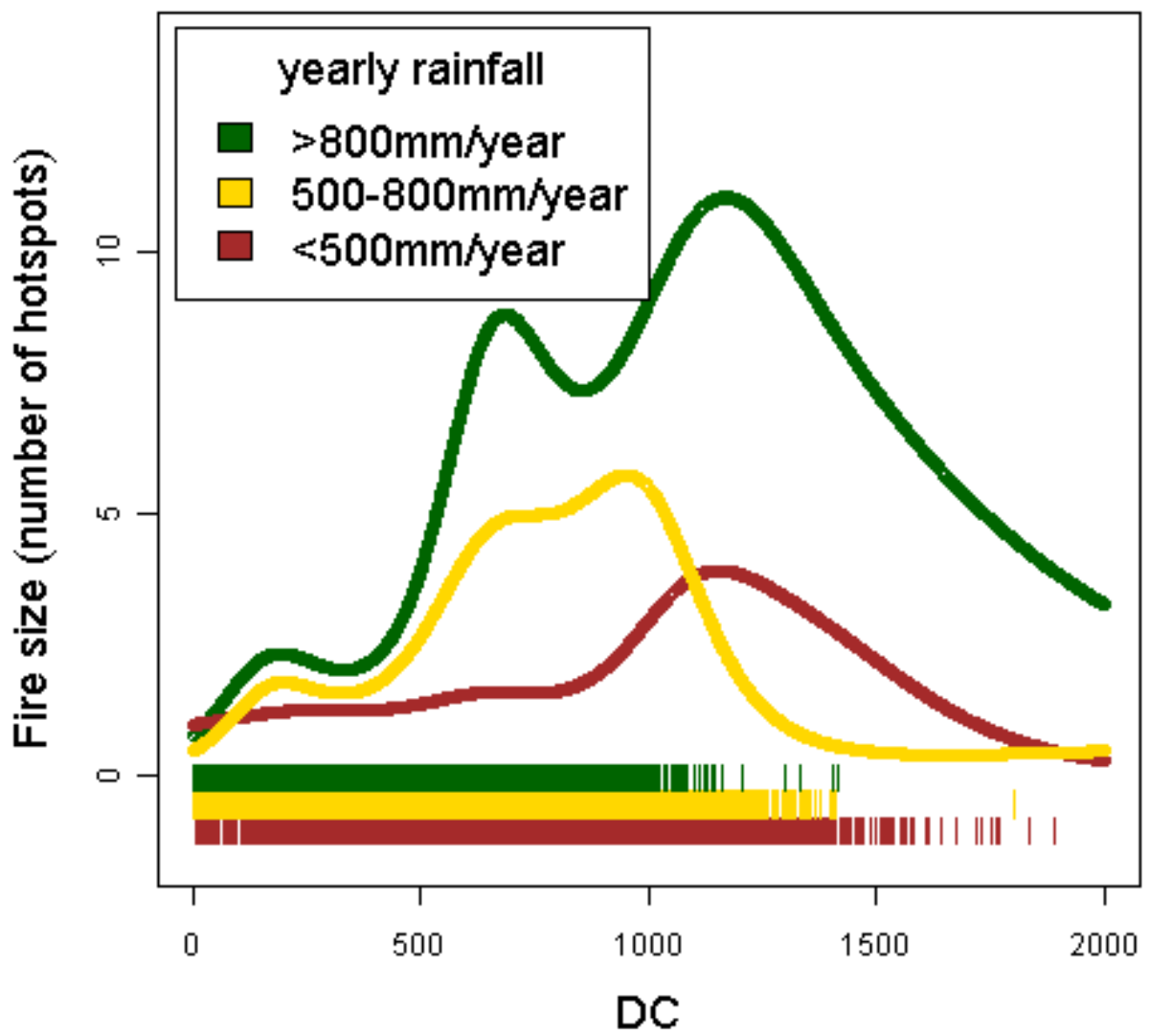

Fig. 4. Fitting of general Additive Models of fire size response of all fires to fuel dryness for three rainfall categories, corresponding to regions with different average fuel loading. Yearly rainfall corresponds to the average of 1951-2010 rainfall. Rugs at the bottom show fire occurrence.

\section{BGD}

9, 9065-9089, 2012

Two thresholds determine climatic control of forest-fire size in Europe

L. Loepfe et al.

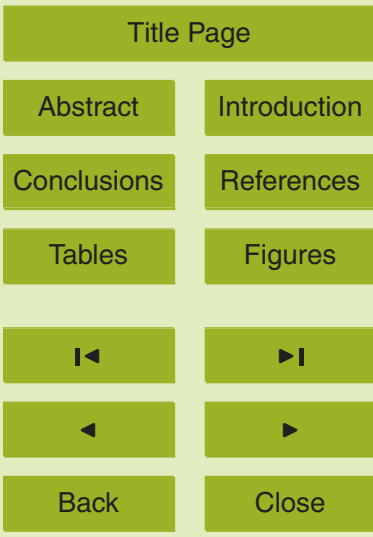

Full Screen / Esc

Printer-friendly Version

Interactive Discussion 


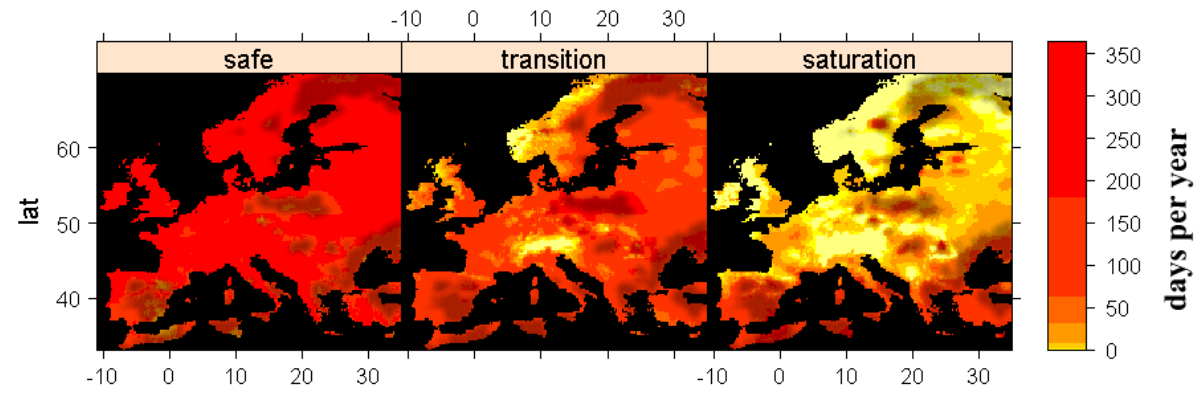

\section{BGD}

9, 9065-9089, 2012

\section{Two thresholds determine climatic control of forest-fire size in Europe}

L. Loepfe et al.

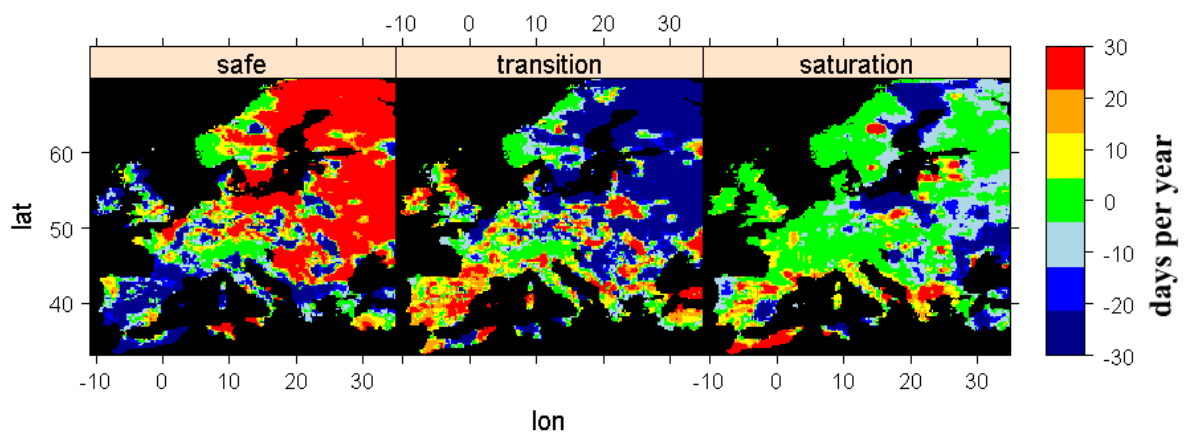

Fig. 5. Average number of days per year that were in the "safe", "transition", or "saturation" segments during the period 1991-2010 and differences compared to the period 1951-1970. The "safe" segment contains DC values below 320, with fire size precluded by high fuel humidity. The "transition" segment includes DC values between 320 and 620, with fire size increasing exponentially with fuel dryness. The "saturation" segment contains DC values above 620 and factors other than fuel dryness-control fire size. Shaded areas correspond to annual rainfall of less than $500 \mathrm{~mm}$.

Title Page

\section{Abstract}

Conclusions

\section{Tables}

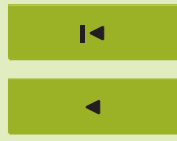

Back
Introduction

References

Figures

$\rightarrow 1$

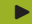

Close

\section{Full Screen / Esc}

Printer-friendly Version

Interactive Discussion 


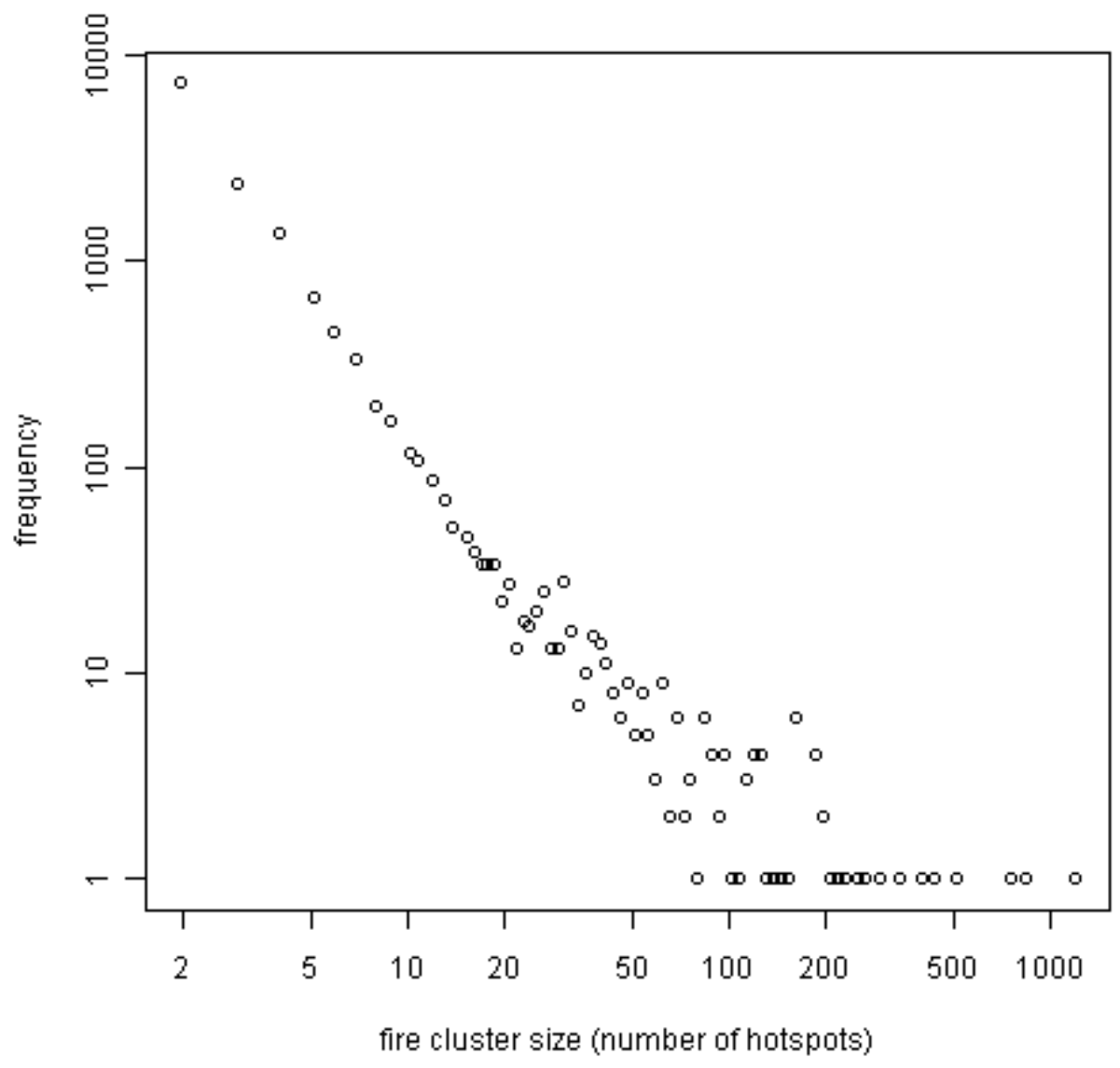

Fig. A1. Fire size distribution of European fires 2001-2010, using logarithmic bins and 100 breaks.

\section{BGD}

9, 9065-9089, 2012

Two thresholds determine climatic control of forest-fire size in Europe

L. Loepfe et al.

Title Page

Abstract

Introduction

Conclusions

References

Tables

Figures

14

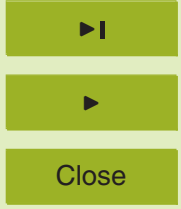

Back

Full Screen / Esc

Printer-friendly Version

Interactive Discussion 